\title{
EFFECTIVENESS OF LOANS OR FINANCING AND PORTFOLIO MANAGEMENT WITH PROBLEMS OR NON-PERFORMING LOANS THE IMPACT ON ASSET GROWTH IN ISLAMIC BANKS IN INDONESIA
}

\author{
Agus Supriatna $^{* 1}$, Faisal ${ }^{2}$ \\ Pamulang University, Indonesia ${ }^{* 12}$ \\ dosen01837@unpam.ac.id8 ${ }^{* 1}$, faisalunpam80@gmail.com²
}

\begin{abstract}
The study was conducted to see whether there was a significant impact of credit or financing and portfolio management of problem loans or non-performing loans on asset growth in Islamic banks in Indonesia in 2009-2018, either partially or simultaneously. This type of research is descriptive quantitative using secondary data types obtained from the published financial reports of three major banks in Indonesia, namely Bank Muamalat Indonesia or BMI, Bank Rakyat Indonesia Syariah or BRI Syariah and Bank Syariah Mandiri or BSM from the Bank's third Annual Report, from 2009 until 2018. The data analysis method uses classical assumption test techniques and Linear Regression Analysis techniques, Correlation Coefficient test, partial Hypothesis test ( $t$ test), simultaneous test ( $F$ test) and Determination Coefficient test with Credit or Financing Effectiveness variables (X1) and Portfolio Management of Non Performing Loans is a variable (X2) and Asset Growth the Islamic Banks in Indonesia as a variable (Y). Tests conducted using the Eviews application version 10 . Then the results of the study with the multiple regression equation $\mathrm{PA}=37.424 .6+1.364393 \mathrm{EK} \_\mathrm{P}$ + 3.289641 NPL with the value of Fcount (595.2748)> from Ftable $(2,3003)$ significance or probability (a) $0.000<0.05$. Simultaneously Effectiveness of Credit or Financing and Portfolio Management of Non Performing Loans simultaneously have an impact on Asset Growth in Islamic Banks in Indonesia. The Adjusted R-Square (R2) value of 0.976182 shows that the contribution of the EK_P and NPL variables to the PA variable is $97.6182 \%$ while $2.3818 \%$ is seen by other factors.
\end{abstract}

Keywords: Effectiveness of Credit, Financing, Portfolio, Non Performing Loan, Islamic Banks

\section{INTRODUCTION}

Company will develop and progress, one of which can be seen from how much growth of its assets, supported by the ability to manage business activities that are closely related to the company's main business. Likewise with the banking world, one indicator in observing the growth and progress of a bank is the increase in bank assets. As for the increase and decrease in assets in the banking sector in general, cannot be separated from the activities of lending or financing to the public and the quality of the credit or financing. This has become the basis for my thinking to make research that will be carried out, namely regarding the world of banking, especially Islamic banks in Indonesia in managing credit or financing portfolios that have a major impact on the development or growth of
Islamic banking in Indonesia today.Research background, namely Indonesia is a country with a majority Muslim population and it can be said that the largest in the world is an extraordinary market share, but Islamic banking has only contributed around $4.81 \%$ to the market share with an asset growth of around $11.97 \%$ in June 2016 until December 2016 the market share of Islamic banking was still around $5.33 \%$ of all banking assets. Judging from the growth of funds in 2018 was smaller than 2017, the biggest decline was in deposit growth, which fell from $10.8 \%$ in August 2017 to $3.4 \%$ in August 2018 even though credit growth increased significantly in the same period from $8.14 \%$ to $12.7 \%$. This decrease in liquidity and slower growth will have the potential to encourage an increase in non-performing loans. This 
can be shown by the 2017 NPL ratio of $2.59 \%$, up to $2.74 \%$ in September 2018, when there was a significant increase in credit growth, this is very ironic. This means that NPL growth is faster than credit growth and improvement in NPLs. This figure shows that Islamic banking still needs good management so that it can keep up with the growth of conventional banking. The data in this study is secondary data, from 2009 to 2018. The components used for this study use data on the number of credit or financing customers and the existing or existing credit portfolios and managed NPL / NPF of each bank studied. Specifically for the object of this research, the writer tries to display the financial statements of several Islamic banks, including Bank Muamalat Indonesia or BMI, Bank Rakyat Indonesia Syariah or BRI Syariah and Bank Syariah Mandiri or BSM. This test was conducted to answer the research hypothesis that was stated, namely the significant influence of the effectiveness of credit or financing and management of nonperforming loan portfolios on asset growth in Islamic banks in Indonesia. However, what will be tested in this study is the effectiveness of credit or financing, which is the net total of the amount of credit or financing that has been reduced by the amount of allowance for accounts receivable write-offs and Management of the Non-Performing Loans Portfolio, which is the amount of net NonPerforming Loans / Finacing occurs in these Islamic banks, while asset growth in Islamic banks in Indonesia is the amount of net assets that can be recorded by the Islamic bank in the period from 2009 to 2018 which is based on a published summary of financial data reports. with the following table

Table 1. Data on Total Credit / Financing, NPL / F and Total Asset at PT. Bank Muamalai Indonesia, Tbk Period 2009-2018 (in million Rupiah)

\begin{tabular}{rrrr}
\hline Years & $\begin{array}{c}\text { Total Credit / Financing } \\
\text { (Net) }\end{array}$ & $\begin{array}{c}\text { Non Performing Loan } \\
\text { Portfolio / NPL (Net) }\end{array}$ & Total Asset \\
\hline 2009 & 10.704 .767 & 345.498 & 16.027 .179 \\
2010 & 15.018 .088 & 88.075 & 21.400 .793 \\
2011 & 21.727 .329 & 75.134 & 32.479 .507 \\
2012 & 32.241 .456 & 594.436 & 44.854 .413 \\
2013 & 40.922 .616 & 321.096 & 54.694 .021 \\
2014 & 41.613 .619 & 2.057 .670 & 62.442 .190 \\
2015 & 38.825 .318 & 1.709 .005 & 57.172 .588 \\
2016 & 38.334 .745 & 560.125 & 55.786 .398 \\
2017 & 39.964 .561 & 1.136 .141 & 61.696 .920 \\
2018 & 32.360 .823 & 860.410 & $57.227,276$ \\
\hline
\end{tabular}

Source: Data processed from Bank Muamalat's Annual Repor Financial Report

Table 2. Total Credit / Financing Data, Npl / F And Total Asset At Pt. Bank Rakyat Indonesia Syariah, Tbk Period 2009-2018 (In Million Rupiah)

\begin{tabular}{rrrr}
\hline Years & $\begin{array}{c}\text { Total Credit / Financing } \\
\text { (Net) }\end{array}$ & $\begin{array}{c}\text { Non Performing Loan Portfolio } \\
\text { / NPL (Net) }\end{array}$ & Total Asset \\
\hline 2009 & 2.514 .185 & 26.919 & 3.178 .386 \\
2010 & 5.414 .009 & 115.168 & 6.856 .386 \\
2011 & 8.970 .274 & 191.362 & 11.200 .823 \\
2012 & 11.010 .637 & 210.950 & 14.088 .914 \\
2013 & 13.778 .031 & 445.070 & 17.400 .691 \\
2014 & 15.322 .904 & 569.715 & 20.341 .033 \\
2015 & 16.244 .038 & 643.108 & 24.230 .247 \\
2016 & 17.256 .787 & 571.450 & 27.687 .188 \\
2017 & 17.274 .399 & 885.219 & 31.543 .384 \\
2018 & 19.620 .703 & 1.013 .425 & 37.915 .084 \\
\hline
\end{tabular}

Source: Data processed from the BRIS Annual Financial Report 
Table 3. Data on Total Credit / Financing, NPL / F and Total Assets at PT. Bank Syariah Mandiri, Tbk Period 2009-2018 (In Million Rupiah)

\begin{tabular}{rrrr}
\hline Years & $\begin{array}{c}\text { Total Credit / Financing } \\
\text { (Net) }\end{array}$ & $\begin{array}{r}\text { Non Performing Loan } \\
\text { Portfolio / NPL (Net) }\end{array}$ & \multicolumn{1}{c}{ Total Asset } \\
\hline 2009 & 14.099 .277 & 286.689 & 22.036 .535 \\
2010 & 22.999 .664 & 307.578 & 32.481 .873 \\
2011 & 35.557 .137 & 347.016 & 48.671 .950 \\
2012 & 43.301 .405 & 505.593 & 54.229 .396 \\
2013 & 48.669 .398 & 1.150 .512 & 63.965 .361 \\
2014 & 46.576 .875 & 2.135 .983 & 66.955 .671 \\
2015 & 48.491 .724 & 2.063 .631 & 70.369 .709 \\
2016 & 52.837 .460 & 1.733 .438 & 78.831 .722 \\
& & & \\
2017 & 57.977 .439 & 1.634 .743 & 87.939 .774 \\
2018 & 64.901 .059 & 1.008 .846 & 98.341 .116 \\
\hline
\end{tabular}

Source: Data processed from financial statements.

Based on the background of the problems discussed in tables 1,2 and 3, the researcher is interested in examining the relationship between the variables of Total Credit / Financing (Net), NonPerforming Loans (Net) and Total Assets to be stated in the title "Effectiveness Credit or Financing and Portfolio Management with Problems or Non-Performing Loans Its Impact on Asset Growth in Islamic Banks in Indonesia ". Formulation of the problem, based on the background of the problem above, the researcher formulated the masala formulation as follows:Is there a partial effect of Credit Effectiveness or Financing on Asset Growth in Islamic Banks in Indonesia for the Period 2009 2018? Is there a partial effect of NonPerforming Loan (NPL / F) Portfolio Management on Asset Growth in Islamic Banks in Indonesia in 2009 - 2018? Is there a simultaneous influence of Credit Effectiveness or Financing and Portfolio Management of Non-Performing Loans or Non-Performing Loans on Asset Growth in Islamic Banks in Indonesia. 2009 - 2018 period? Research purposes, objective of this research is to find out how much the influence of Credit Effectiveness or Financing and Portfolio Management with Problems or Non-Performing Loans partially or simultaneously on Asset Growth in Islamic Banks in Indonesia. So that it can be used as evaluation material and special input to the company and the general public as well as material for consideration and reference for decision making to be carried out by the competent authorities. Definition of Sharia Bank According to Mudrajat and Suhardjono (2002: 593) Islamic banks are banks that operate in accordance with the principles of Islamic sharia, which refers to the provisions in the provisions of the Qur'an and Hadith. Meanwhile, according to Totok and Sigit (2006: 153), Islamic banks are banks which in their activities both raise funds and in the context of channeling funds provide and charge rewards based on the principle of buying and selling and profit sharing. The main principle of operation of Islamic banks is Islamic law which is sourced from the Koran and Hadith. Bank operations must pay attention to the orders and prohibitions in the Qur'an and the sunnah of the Prophet Muhammad SAW. The prohibition mainly relates to bank activities which can be classified as usury. Sharia Banking Business Activities One of the basic characteristics that differentiate between Islamic banks and conventional banks lies in the products they offer. Islamic banks try their best to avoid usury practices which are represented by the interest system. In its development, in Indonesia, based on article 2 (3) PBI 7/46 / PBI / 2005 it is stated that not only the interest system (which is often generally equated with usury) that cannot exist in sharia transactions, but also gharar, maysir, riba, zalim, riswah, haram and immoral goods. Those are the general principles that are emphasized in all products of Islamic banks. Islamic banking business activities are confirmed in Law 
No. 10/1998 and its implementing regulations. The articles that confirm this are article 1 paragraph (12) and paragraph (13), article 6 letter $\mathrm{m}$, article 7 letter c, article 8 paragraph (1) and paragraph (2), article 11 paragraph (1) and paragraph ( $4 a)$, article 13 letter c, article 29 paragraph (3) and article 37 paragraph (1) letter c. This provision is reinforced again by the decision of the board of directors No 32/34 / Kep / Dir. May 12, 1999 articles 28 and 29 concerning commercial banks based on sharia principles for Islamic commercial banks. Definition of financing, according to $\mathrm{RI}$ Law no. 10 Article 1 (2) regarding amendments to Law no. 7 of 1992 concerning banking: "Financing based on sharia principles is the provision of money or equivalent claims, based on an agreement or agreement between the bank and another party which requires the financed party to return the money or claim after a certain period of time in exchange for or for the result. Musharaka financing, according to Sri and Wasilah (2008: 135), the types of musyarakah contracts are divided into two, namely: Syirkah Al Milk contains the meaning of co-ownership and its existence arises when two or more people acquire joint ownership of a wealth (asset). Example: in the form of ownership of a type of item (for example, a house) that is purchased together. ljarah financing, according to Adiwarman (in the Fatwa of the National Sharia Council, 2001: 55) ijarah can be defined as follows: "contract of transfer of use rights (benefits) for a good or service, within a certain time through payment of rental wages (ujrah), without being followed the stuff itself ". Mudharabah Financing Al-mudharabah is a business cooperation agreement between two parties in which the first party (shahibul maal) provides all (100\%) of the capital, while the other party becomes the manager (mudharib). Profits from mudaraba are divided according to the agreement set forth in the contract, whereas if the loss is borne by the owner of the capital as long as the loss is not the result of negligence of the manager. If the loss is caused by the negligence of the manager, the management must be responsible for the loss. (Syafi'i Antonio, Muhammad, 2001: 95)

Murabahah financing, according to Adiwarman A. Karim (in Islamic Bank, 2004: 113) it can be defined as follows: "contract for sale and purchase of goods by stating the acquisition price and profit (margin) agreed upon by the seller and the buyer". So this contract is a form of natural certainty contract, because in murabahah it is determined how much the required rate of profit is (the profit to be obtained). Management, According to Hasibuan (2017: 1) management is the science and art of regulating the process of utilizing human resources and other sources effectively and efficiently to achieve certain goals. And according to Veithzal Rivai Zaenal (2015: 4) management has the meaning as a collection of knowledge about how to manage human resources. Based on the above understanding, it can be concluded that financial management is all company activities related to how to acquire, use, manage assets according to the overall objectives of the company. Effectiveness, according to Ravianto, "effectiveness is how well the work is done, to what extent people produce the expected output. This means that if a job can be completed in accordance with the plan, both in time, cost and quality, it can be said to be effective. " And according to Prasetyo Budi Saksono that the definition of "effectiveness is how much the level of attachment between the" output "achieved with the expected output from the number of inputs" input "in a company or a person" Credit or Financing, according to Veithzal Rivai and Arviyan Arifin in Islamic Banking that other definitions of financing according to Law No.7 of 1992 concerning banking as amended by Law No.10 of 1998 concerning Banking in Article 1 Number 12, among others; "Financing based on sharia principles is the provision of money or claims equivalent to that, based on an agreement or agreement between the bank and another party which requires the financed party to return the money or bill after a certain period of time in exchange for profit sharing", and number 13 ; "Sharia principles are rules of agreements based 
on Islamic law between banks and other parties for the deposit of funds and / or financing of business activities, or other activities declared in accordance with sharia, including financing based on the principle of profit sharing (mudharabah), financing based on the principle of equity participation (musyarakah). ), the principle of buying and selling goods by obtaining profit (murabahah), or financing capital goods based on the principle of pure lease without choice (ijarah), or with the option of transferring ownership of goods leased from the bank by another party (ijarah wa iqtina). " Definition of non-performing loans or financing or NPL / F

According to the dictionary of Bank Indonesia, NPL is a non-performing loan consisting of loans classified as substandard, doubtful and non-performing. NPL or non-performing loans is one of the main parameters in assessing the performance of functions in the banking sector and other financial institutions. Credit quality consists of 5 categories; known as collectibility. The collectability status in the banking world is classified by the central bank into five status / five kolek from the highest to the lowest. The best collectibility is given a number of 1 : current credit. Then consecutively the collectibility decreased into categories: 2 (Special Mention), 3 (Substandard), 4 (Doubtful) and 5 (Loss). Loans with collectibility 1 and 2 are categorized as current loans. Meanwhile, loans with a collectibility of 3 to 5 are categorized as non-performing loans (NPL). And according to Julius $R$ Latumerrissa (2001: 70) Non Performing Loan (NPL) can be interpreted as: Credit which repayments of principal debt and interest obligations do not comply with the terms or conditions set by the bank, and has the risk of receiving income and even has the potential to lose .Asset Growth, according to Aries Heru Prestyo (2011: 110) states that Asset growth is "Company growth is always synonymous with company assets (both physical assets such as land, buildings, buildings and financial assets such as cash, receivables and so on). The asset paradigm as an indicator of company growth is commonly used. The total value of assets in the balance sheet determines the company's wealth. " Asset growth shows which are assets used for company operations. And furthermore Aries Heru Prestyo (2011: 143) also states that company growth is "Growth variable can be seen from the side of sales, assets and company net income. Although it can be seen from various sides, all three use the same basic principle where growth is understood as an increase in value in a period relative to the previous period. "

\section{METHODS}

In this study, data collection methods or techniques are used with library research (Library Research), and conducting observations on research objects with the aim of obtaining secondary data, namely by conducting research on the official website of Bank Muamalat Indonesia or BMI, Bank Rakyat Indonesia Syariah or BRI Syariah. and Bank Syariah Mandiri or BSM as well as trying to obtain various data and other information that is related and can support this research. This research is a type of quantitative research using data processing methods using Microsoft Excel and Eviews10. The data obtained by the author in the observation period 2009-2018 According to Dwi Priyanto (2013: 40-41) the underlying assumptions of linear regression analysis are that the data distribution is normal and the relationship between the dependent variable and each independent variable is linear. In addition, there is a classic assumption tester that is usually used in economic research, namely the absence of multicolinearity, heterocedasticity, and autocorrelation in the regression model. The data analysis methods used are: Statistic test, analytical method used in this research is using the SPSS method (Statistical Product Service and Solution). SPSS is a program or software used to manage statistical data. Classical assumption test: 1 . Normality Test 2. Multicollinearity Test 3 . Heteroscedasticity Test 4. Autocorrelation Test . Hypothesis Analysis 
Hypothesis test $(\mathrm{t})$, $\mathrm{f}$ test (simultaneous testing), multiple regression model equations.

\section{RESULTS AND DISCUSSION}

Table 2. Descriptive statistics

\begin{tabular}{lccc}
\hline & EK_P & NPL & TA \\
\hline \hline Mean & 29151024 & 786466.8 & 42734884 \\
Median & 27620560 & 570582.5 & 41384749 \\
Maximum & 64901059 & 2135983. & 98341116 \\
Minimum & 2514185. & 26919.48 & 3178386. \\
Std. Dev. & 17034392 & 645780.0 & 25069557 \\
Skewness & 0.285957 & 0.846828 & 0.313751 \\
Kurtosis & 1.951248 & 2.503009 & 2.216054 \\
& & & \\
Jarque-Bera & 1.783708 & 3.894341 & 1.260413 \\
Probability & 0.409895 & 0.142677 & 0.532482 \\
Sum & $8.75 \mathrm{E}+08$ & 23594003 & $1.28 \mathrm{E}+09$ \\
Sum Sq. Dev. & $8.41 \mathrm{E}+15$ & $1.21 \mathrm{E}+13$ & $1.82 \mathrm{E}+16$ \\
& & & \\
Observations & 30 & 30 & 30 \\
\hline \multicolumn{4}{c}{ Source: Data Processing, 2020} \\
\end{tabular}

Based on table 2. the variable of Credit or Financing Effectiveness (EK_P), Non Performing Loans (NPL) and Asset Growth (PA) has the following description:The Credit or Financing Effectiveness variable has a minimum value of $2,514,181$ and a maximum value of $64,901,059$ with an average of $29,151,024$ and a standard deviation of $17,034,392$. The non- performing loan variable has a minimum value of $26,919.48$ and a maximum value of $2,135,983$ with an average of $786,466.8$ and a standard deviation of 645,780 . The Asset Growth variable has a minimum value of $3,178,386$ and a maximum value of $98,341,116$ with an average of $42,734,884$ and a standard deviation of $250,695.57$.

\section{Panel Data Regression \\ Metode Ordinary Least Square (OLS) atau Common Effect Model (CEM)}

Table. 3. Panel data regression results with the Common Effect Model Method Dependent Variable: TA Method: Panel Least Squares

Date: 09/16/20 Time: 06:31

Sample: 20092018

Periods included: 10

Cross-sections included: 3

Total panel (balanced) observations: 30

\begin{tabular}{crrrr}
\hline \hline Variable & Coefficient & Std. Error & t-Statistic & Prob. \\
\hline \hline CK & 374243.6 & 1417998. & 0.263924 & 0.7938 \\
NPL & 1.364393 & 0.059677 & 22.86280 & 0.0000 \\
& 3.289641 & 1.574171 & 2.089760 & 0.0462 \\
\hline \hline R-squared & 0.977824 & Mean dependent var & 42734884 \\
Adjusted R-squared & 0.976182 & S.D. dependent var & 25069557 \\
S.E. of regression & 3869032. & Akaike info criterion & 33.26955
\end{tabular}




\begin{tabular}{lrll} 
Sum squared resid & $4.04 \mathrm{E}+14$ & Schwarz criterion & 33.40967 \\
Log likelihood & -496.0432 & Hannan-Quinn criter. & 33.31437 \\
F-statistic & 595.2748 & Durbin-Watson stat & 0.474294 \\
Prob(F-statistic) & 0.000000 & & \\
\hline
\end{tabular}

\section{Metode Fixed Effect (Fixed Effect Model /FEM)}

Table. 4. Panel data regression results with the Fixed Effect Model Method Dependent Variable: TA

Method: Panel Least Squares

Date: 09/16/20 Time: 06:34

Sample: 20092018

Periods included: 10

Cross-sections included: 3

Total panel (balanced) observations: 30

\begin{tabular}{|c|c|c|c|c|}
\hline Variable & Coefficient & Std. Error & t-Statistic & Prob. \\
\hline C & -982310.4 & 2046341. & -0.480033 & 0.635 \\
\hline EK_P & 1.417962 & 0.086294 & 16.43178 & 0.0000 \\
\hline$N \overline{P L}$ & 3.028945 & 1.641445 & 1.845292 & 0.0769 \\
\hline \multicolumn{5}{|c|}{ Effects Specification } \\
\hline \multicolumn{5}{|c|}{ Cross-section fixed (dummy variables) } \\
\hline R-squared & 0.979353 & \multirow{7}{*}{\multicolumn{2}{|c|}{$\begin{array}{l}\text { Mean dependent var } \\
\text { S.D. dependent var } \\
\text { Akaike info criterion } \\
\text { Schwarz criterion } \\
\text { Hannan-Quinn criter. } \\
\text { Durbin-Watson stat }\end{array}$}} & \multirow{7}{*}{$\begin{array}{r}42734884 \\
25069557 \\
33.33145 \\
33.56498 \\
33.40616 \\
0.541192\end{array}$} \\
\hline Adjusted R-squared & 0.976050 & & & \\
\hline S.E. of regression & 3879746. & & & \\
\hline Sum squared resid & $3.76 \mathrm{E}+14$ & & & \\
\hline Log likelihood & -494.9717 & & & \\
\hline F-statistic & 296.4586 & & & \\
\hline Prob(F-statistic) & 0.000000 & & & \\
\hline
\end{tabular}

\section{Metode Random Effect (Random Effect Model/REM)}

Table. 5. Panel data regression results with the Random Effect Model Method Dependent Variable: TA

Method: Panel EGLS (Cross-section random effects)

Date: 09/16/20 Time: 06:35

Sample: 20092018

Periods included: 10

Cross-sections included: 3

Total panel (balanced) observations: 30

Swamy and Arora estimator of component variances

\begin{tabular}{ccccc}
\hline \hline Variable & Coefficient & Std. Error & t-Statistic & Prob. \\
\hline \hline C & 374243.6 & 1421924. & 0.263195 & 0.7944 \\
EK_P & 1.364393 & 0.059843 & 22.79967 & 0.0000 \\
NPL & 3.289641 & 1.578530 & 2.083989 & 0.0468 \\
\hline \hline
\end{tabular}

Effects Specification 


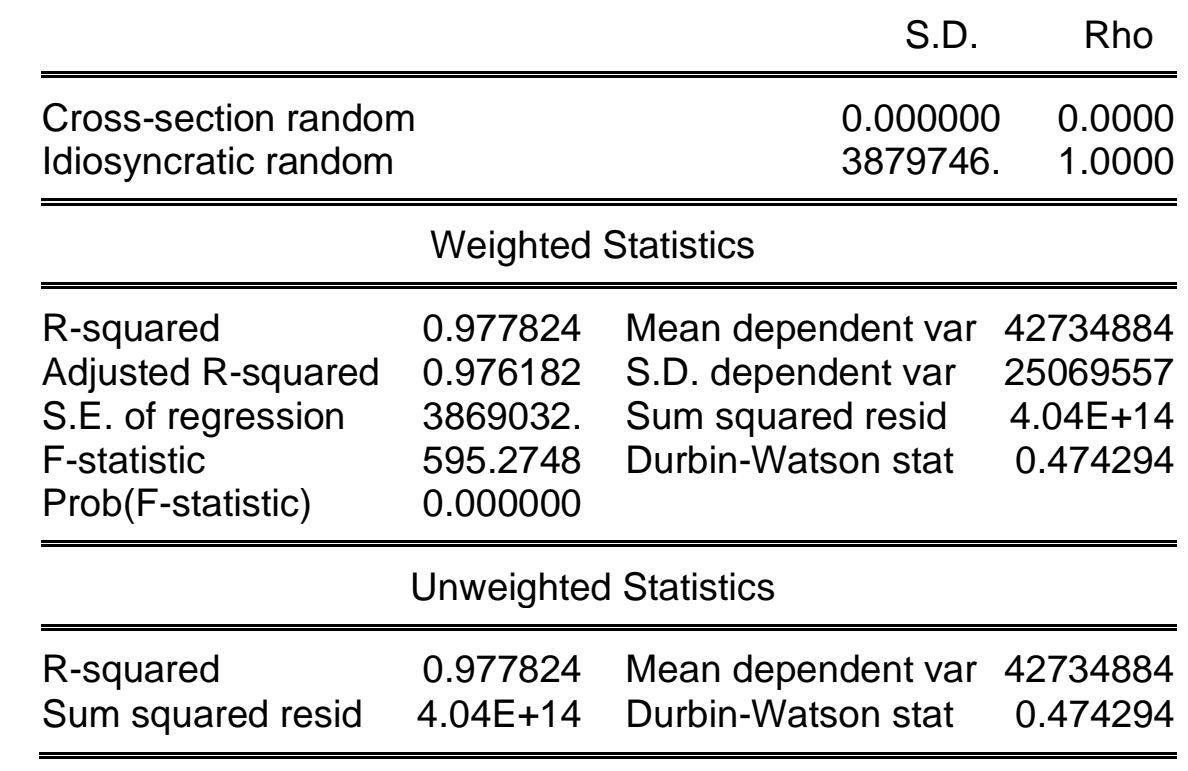

\section{Panel Data Model Suitability Testing} Uji Chow-Test (Common Effect vs Fixed Effect)

Table. 5. Chow Test Results with PA as the dependent variable Redundant Fixed Effects Tests

Equation: RANDOM

Test cross-section fixed effects

\begin{tabular}{lcrc}
\hline \hline Effects Test & Statistic & d.f. & Prob. \\
\hline \hline Cross-section F & 0.925544 & $(2,25)$ & 0.4095 \\
Cross-section Chi-square & 2.142915 & 2 & 0.3425 \\
\hline \hline
\end{tabular}

Source: data processed with eviews 10

Based on the test results and calculations shown in table 5 , which is shown by prob. The F-test (F-test) of 0.4095 concluded that from the chow-test, it was seen that the probability value of the $F$ test was 0.4095 and the chi-square test of 0.3425 was greater than $\alpha=0.05(5 \%)$, so $\mathrm{H} 1$ was rejected and $\mathrm{H} 0$ was accepted. , which means that the common effect model is better used in estimating panel data regression than the fixed effect model.

\section{Haustman Test (Fixed Effect vs Random Effect)}

Table. 6. Hausman Test with PA as the dependent variable Redundant Fixed Effects Tests

Equation: RANDOM

Test cross-section fixed effects

\begin{tabular}{|c|c|c|c|}
\hline Effects Test & Statistic & d.f. & Prob. \\
\hline Cro & 0.925544 & $(2,25)$ & 0.4095 \\
\hline Cross-section Chi-square & 2.142915 & 2 & 0.3425 \\
\hline
\end{tabular}

Source: data processed with eviews 10 
Based on the results of the Hausman test calculations shown in table 4.6, it is concluded that the Chi-Square probability value of 0.3425 is greater than $\alpha$
$=0.05(5 \%)$, so accept $\mathrm{HO}$ is accepted. Then the panel data regression used in this study is a random effect model

\section{Langrage Multiplier Test (Common Effect vs Random Effect)}

Table. 7. LM Test Results with PA as the dependent variable Lagrange multiplier (LM) test for panel data

Date: 09/16/20 Time: 18:09

Sample: 20092018

Total panel observations: 30

Probability in ()

\begin{tabular}{|c|c|c|c|}
\hline $\begin{array}{l}\text { Null (no rand. } \\
\text { effect) } \\
\text { Alternative }\end{array}$ & $\begin{array}{c}\text { Cross- } \\
\text { section } \\
\text { One-sided }\end{array}$ & $\begin{array}{c}\text { Period } \\
\text { One-sided }\end{array}$ & Both \\
\hline Breusch-Pagan & $\begin{array}{l}0.411195 \\
(0.5214)\end{array}$ & $\begin{array}{l}18.54870 \\
(0.0000)\end{array}$ & $\begin{array}{l}18.95989 \\
(0.0000)\end{array}$ \\
\hline
\end{tabular}

Source: data processed with eviews 10

Based on the results of the calculation of the LM-test Breusch-Pagan (BP) 0.0000 smaller than $\alpha=0.05$, it can be concluded that the random effect model is better than the common effect model in estimating the determinants of Asset Growth in Islamic Banks in Indonesia.

\section{Model Conclusion}

Based on the paired test results using the Chow test, the LM BreuschPagan (BP) test, and the Hausmant test on the three panel data regression methods above, it can be concluded that the random effect model in the panel data regression method is further used to estimate and analyze factors. which affects Asset Growth for the 2009-2018 period in Islamic Banks in Indonesia.

\section{Classic assumption test}

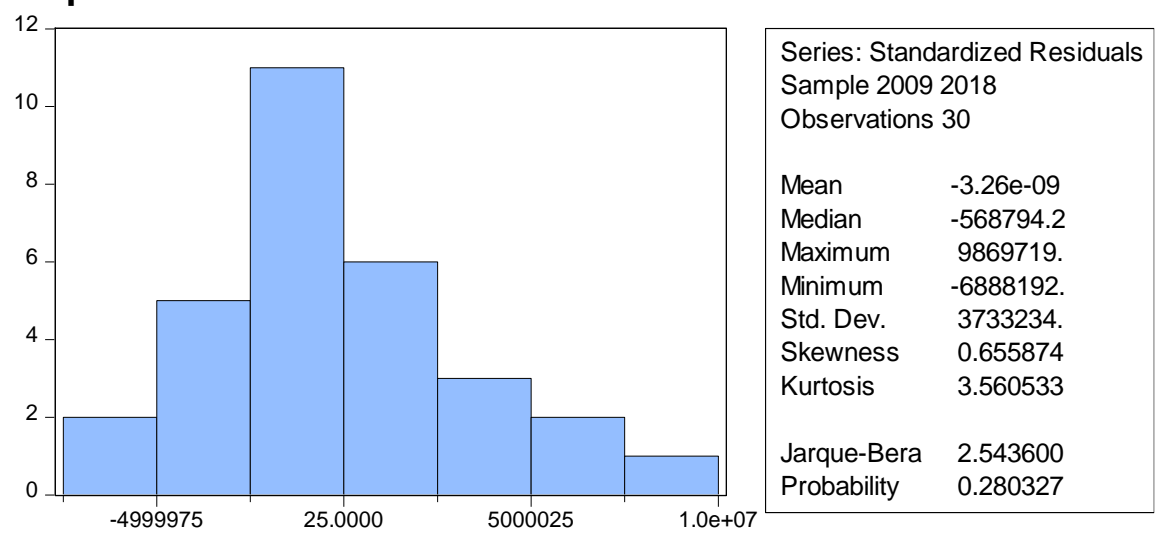

Figure 1. Image of Residue Histogram Graph

Source: Data processing (2020) 
Based on the histogram graph above, it is obtained the Jarque-Bera (JB) value of 1.519521 , with a probability value of $0.280327>0.05$, which means that the data in this study are normally distributed.

\section{Multi-collinearity test}

Date: 09/16/20 Time: $21: 19$

Table 8. Multicollinearity Testvariance Inflation Factors

Sample: 130

Included observations: 30

\begin{tabular}{lrrr}
\hline \multicolumn{3}{c}{ Coefficient } & \multicolumn{2}{c}{$\begin{array}{c}\text { Uncentered } \\
\text { Variable }\end{array}$ Variance } & Centered \\
VIF & \multicolumn{1}{c}{ VIF } \\
\hline & & & \\
EK_P & 0.003561 & 8.067198 & 2.002011 \\
NPL & 2.478016 & 5.073730 & 2.002011 \\
C & $2.01 E+12$ & 4.029653 & NA \\
\hline
\end{tabular}

Source: Data processing (2020)

From the table above, it is known that there is no multicollinearity problem, this can be seen from the VIF value on the Centered VIF for the two independent variables is less than 10 . Where the
Centered VIF value for Credit or Financing Effectiveness is 2.002011 and the NPL is 2.002011 less than 10. So it can be concluded that there is no multicollinearity problem from the independent variables.

Table 9. Heteroscedasticity Test

Heteroscedasticity Test

Heteroskedasticity Test: White

\begin{tabular}{llll}
\hline \hline F-statistic & 1.864131 & Prob. F(5,24) & 0.1383 \\
Obs ${ }^{*}$-squared & 8.391782 & Prob. Chi-Square(5) & 0.1359 \\
Scaled explained & & & \\
SS & 8.702411 & Prob. Chi-Square(5) & 0.1215 \\
\hline \hline
\end{tabular}

Source: Data processing (2018)

From the output table above, it can be seen that there is no heterosxasticity problem. This is because the Chi-Square probability is more than 0.05 .

Table 10. Panel Data Regression Analysis

Panel Data Regression Test Results with Random Effects Method Dependent Variable: TA

Method: Panel EGLS (Cross-section random effects)

Date: 09/16/20 Time: 06:35

Sample: 20092018

Periods included: 10

Cross-sections included: 3

Total panel (balanced) observations: 30

Swamy and Arora estimator of component variances

Variable Coefficient Std. Error t-Statistic Prob.




\begin{tabular}{|c|c|c|c|c|}
\hline $\begin{array}{c}\mathrm{C} \\
\mathrm{EK} P \\
\mathrm{NPL}\end{array}$ & $\begin{array}{l}374243.6 \\
1.364393 \\
3.289641\end{array}$ & $\begin{array}{l}1421924 \\
0.059843 \\
1.578530\end{array}$ & $\begin{array}{l}0.263195 \\
22.79967 \\
2.083989\end{array}$ & $\begin{array}{l}0.7944 \\
0.0000 \\
0.0468\end{array}$ \\
\hline & \multicolumn{2}{|c|}{ Effects Specification } & $c \Omega$ & \\
\hline $\begin{array}{l}\text { Cross-section randon } \\
\text { Idiosyncratic random }\end{array}$ & & & $\begin{array}{l}0.000000 \\
3879746 .\end{array}$ & $\begin{array}{l}0.0000 \\
1.0000\end{array}$ \\
\hline \multicolumn{5}{|c|}{ Weighted Statistics } \\
\hline $\begin{array}{l}\text { R-squared } \\
\text { Adjusted R-squared } \\
\text { S.E. of regression } \\
\text { F-statistic } \\
\text { Prob(F-statistic) }\end{array}$ & $\begin{array}{l}0.977824 \\
0.976182 \\
3869032 . \\
595.2748 \\
0.000000\end{array}$ & \multicolumn{2}{|c|}{$\begin{array}{l}\text { Mean dependent var } \\
\text { S.D. dependent var } \\
\text { Sum squared resid } \\
\text { Durbin-Watson stat }\end{array}$} & $\begin{array}{r}42734884 \\
25069557 \\
4.04 \mathrm{E}+14 \\
0.474294\end{array}$ \\
\hline \multicolumn{5}{|c|}{ Unweighted Statistics } \\
\hline $\begin{array}{l}\text { R-squared } \\
\text { Sum squared resid }\end{array}$ & $\begin{array}{l}0.977824 \\
4.04 E+14\end{array}$ & $\begin{array}{l}\text { Mean depe } \\
\text { Durbin-Wat }\end{array}$ & $\begin{array}{l}\text { ndent var } \\
\text { son stat }\end{array}$ & $\begin{array}{r}42734884 \\
0.474294\end{array}$ \\
\hline
\end{tabular}

From the data above, the regression equation is obtained:

$P A=37,424,6+1,364393$ EK_P $+3,289641 \mathrm{NPL}$ The meaning of these numbers is as follows: (which is defined as the coefficient value of the independent variable that has a significant effect, namely the significance value of less than 0.05) The constant is $37,424.6$, meaning that if the EK_P and NPL values are 0 , then the $P A$ value is $37,424.6$. The regression coefficient for the EK_P variable is positive
1.364393, meaning that each increase in EK_P is one unit, it will increase the PA by 1.364393 units, assuming the other independent variables are constant. The regression coefficient for the NPL variable is positive 3.289641 , which means that for each increase in NPL by one unit, it will increase the PA by 3.289641 units, assuming other independent variables have a fixed value.

\section{Research result \\ $T$ test (partial test)}

Table 11. T Test Results

\begin{tabular}{crrrr}
\hline Variable & Coefficient & Std. Error & t-Statistic & Prob. \\
\hline \hline C & 374243.6 & 1421924 & 0.263195 & 0.7944 \\
EK_P & 1.364393 & 0.059843 & 22.79967 & 0.0000 \\
NPL & 3.289641 & 1.578530 & 2.083989 & 0.0468 \\
\hline \hline
\end{tabular}

\section{Effect of Credit or Financing Effectiveness (EK_P) on Asset Growth (PA).}

The $t$ test results of the effect of the effectiveness of credit or financing on asset growth obtained a positive $t$ count of 22.79967. While the value of $t$ table for $n=$
30 and $\mathrm{dk}=\mathrm{n}-2=40-2=28$ at the significance level $\alpha=0.05$, it is obtained $t$ table $=2.048$. Because the value of tcount (22.79967) $>\mathrm{t}$ table (2.048) with a significance level $(\alpha)$ of $0.000<0.05$, then $\mathrm{Ha} 1$ is accepted and Ho1 is rejected. So it can be concluded that Financial 
Effectiveness or Financing partially affects Asset Growth in Islamic Banks in Indonesia.

\section{The Effect of Non-Performing Loan (NPL) Portfolio Management on Asset Growth} (PA).

The $t$ test results of the effect of financial or financing effectiveness on asset growth obtained a positive t-count of
2.083989. Because the value of $t$ count (2.083989) $>\mathrm{t}$ table (2.048) with a significance level value $(\alpha)$ of $0.0489<0.05$, then $\mathrm{Ha} 2$ is accepted and $\mathrm{Ho} 2$ is rejected. So it can be concluded that the Management of the Non-Performing Loan Portfolio or Non-Performing Loans partially affects Asset Growth in Islamic Banks in Indonesia.

\section{Simultaneous Test (Test F)}

Table 12. F-Test Results Effect of EK_P and NPL on PA

Dependent Variable: TA

Method: Panel EGLS (Cross-section random effects)

Date: 09/16/20 Time: 06:35

Sample: 20092018

Periods included: 10

Cross-sections included: 3

Total panel (balanced) observations: 30

Swamy and Arora estimator of component variances

\begin{tabular}{lrlll}
\hline \hline \multicolumn{1}{c}{ Variable } & Coefficient & Std. Error & t-Statistic & Prob. \\
\hline \hline CK & 374243.6 & 1421924. & 0.263195 & 0.7944 \\
NK_P & 1.364393 & 0.059843 & 22.79967 & 0.0000 \\
NPL & 3.289641 & 1.578530 & 2.083989 & 0.0468 \\
R-squared & 0.977824 & Mean dependent var & 42734884 \\
Adjusted R-squared & 0.976182 & S.D. dependent var & 25069557 \\
S.E. of regression & 3869032. & Sum squared resid & $4.04 \mathrm{E}+14$ \\
F-statistic & 595.2748 & Durbin-Watson stat & 0.474294 \\
Prob(F-statistic) & 0.000000 & & & \\
\hline \hline
\end{tabular}

From the table above, it is obtained that the Fcount value is 595.2748. While the value of Ftable at the $5 \%$ significance level and degrees of freedom (dk) numerator $=\mathrm{k}$ (many independent variables) $=2$ and $\mathrm{dk}$ denominator $=\mathrm{n}-\mathrm{k}-1$ $=30-2-1=27$, the value of Ftable = 3.35 is obtained. If the value of Fcount is compared with Ftable, it will be seen that
Fcount (595.2748)> from Ftable (2.3003) with a significance level or probability ( $\alpha$ ) $0.000<0.05$ is significant. This means that $\mathrm{Ho}$ is rejected and $\mathrm{Ha}$ is accepted. So it can be concluded that the Effectiveness of Credit or Financing and Portfolio Management of Non-Performing Loans simultaneously affects Asset Growth in Islamic Banks in Indonesia. 


\section{Table 13. The coefficient of determination of the contribution of EK_P and NPL to PA. Determination Coefficient Test Results Contribution of EK_P and NPL to PA}

Dependent Variable: TA

Method: Panel EGLS (Cross-section random effects)

Date: 09/16/20 Time: 06:35

Sample: 20092018

Periods included: 10

Cross-sections included: 3

Total panel (balanced) observations: 30

Swamy and Arora estimator of component variances

\begin{tabular}{lrlll}
\hline \hline \multicolumn{1}{c}{ Variable } & Coefficient & Std. Error & t-Statistic & Prob. \\
\hline \hline CK & 374243.6 & 1421924. & 0.263195 & 0.7944 \\
NE_P & 1.364393 & 0.059843 & 22.79967 & 0.0000 \\
NPL & 3.289641 & 1.578530 & 2.083989 & 0.0468 \\
\hline \hline & & & & \\
R-squared & 0.977824 & Mean dependent var & 42734884 \\
Adjusted R-squared & 0.976182 & S.D. dependent var & 25069557 \\
S.E. of regression & 3869032. & Sum squared resid & $4.04 \mathrm{E}+14$ \\
F-statistic & 595.2748 & Durbin-Watson stat & 0.474294 \\
Prob(F-statistic) & 0.000000 & & & \\
\hline \hline
\end{tabular}

In table 13. with the amount of Adjusted R-Square (R2) is 0.976182 . This shows that the percentage contribution of the EK_P and NPL variables to the PA variable is $97.6182 \%$ while the remaining $2.3818 \%$ is influenced by other factors outside of this regression model.

Thus, according to the criteria of Johanes Supranto (2002: 122), the value of 0.976182 is in the range $0.80-1.00$ which indicates that the relationship between the independent variable and the dependent variable is very strong.

\section{Regression Model Equations}

Research using panel data regression models is used to see the effect between the independent variable on the dependent variable, the relationship between variable fluctuations and the fundamental factors that influence it can be formulated. Based on the results of E-views 10 above, the regression model equation is obtained as follows:

\section{Multiple Linear Regression Effect of EK_P and NPL on PA}

In table 5. above, the multiple regression equation is obtained:

$P A=374,243,6+1,364393$ EK_P + 3,289641 NPL

The meaning of the multiple regression equation above can be explained by the analysis as follows: The constant number $374,243.6$ states that if the value of the EK P and NPL variables is constant (0), the $P \bar{A}$ variable already has a value of $374,243.6$. The regression coefficient of 1.364393 on the EK_P variable is positive, stating that by assuming the absence of other independent variables, if the EK_P variable is increased by $1 \%$, then PA tends to increase by $1.364393 \%$. The regression coefficient of 3.289641 on the NPL variable is positive, stating that assuming the absence of other independent variables, if the NPL variable is increased by $1 \%$, then NPM tends to increase by $3.289641 \%$.

\section{Discussion}

Based on the results of processing E-views 10 from this study, the authors get the results of panel data analysis testing as follows: 


\section{Testing the Effect of Credit or Financing Effectiveness on Asset Growth, the} tcount (32.85968)> ttable (2.048) and the significance level $(\alpha)$ is 0.0000 $<0.05$. So that $\mathrm{HO}$ is rejected and $\mathrm{H} 1$ is accepted, meaning that partially the effectiveness of finance or financing has an effect on Asset Growth in Islamic Banks in Indonesia.

\section{Testing the Effect of Non-Performing Loan Portfolio Management on Asset Growth}

the value of tcount (6.625421)> ttable (2.048) and significance level $(\alpha)$ is $0.0000<0.05$. So that $\mathrm{HO}$ is rejected and $\mathrm{H} 1$ is accepted, meaning that partially the Non-Performing Loan Portfolio Management has an effect on Asset Growth in Islamic Banks in Indonesia.

\section{Testing the effect of Credit Effectiveness or Financing and Management of Non}

Performing Loans on Asset Growth, the multiple regression equation $\mathrm{PA}=$ 37.424 .6 + 1.364393 EK_P + 3.289641 NPL with Fcount (595.2748)> from Ftable ( 2,3003 ) with a significance level or probability (a) $0,000<0.05$. So that $\mathrm{Ho}$ is rejected and $\mathrm{Ha}$ is accepted, meaning that simultaneously the Effectiveness of Credit or Financing and Portfolio Management of Non-Performing Loans simultaneously affects Asset Growth in Islamic Banks in Indonesia. The Adjusted R-Square (R2) value of 0.976182 shows the contribution of the EK_P and NPL variables to the PA variable of $97.6182 \%$ while the remaining $2.3818 \%$ is influenced by other factors outside of this regression model.

\section{CONCLUSION}

Based on the research results, the following conclusions were obtained: Partially the effectiveness of credit or financing has an effect on the growth of assets in Islamic banks in Indonesia with a value of tcount (32.85968)> ttable (2.048) and a significance level value $(\alpha)$ of 0.0000 $<0.05$. Partially, the Management of Non Performing Loans Portfolio has an effect on
Asset Growth in Islamic Banks in Indonesia, the value of tcount (6.625421)> ttable (2.048) and significance level $(\alpha)$ is $0.0000<0.05$. Simultaneously the Effectiveness of Credit or Financing and Management of Non Performing Loans Portfolio or Non-Performing Loans has an effect on Asset Growth in Islamic Banks in Indonesia, with the multiple regression equation $\mathrm{PA}=37.424 .6+1.364393 \mathrm{EK} P$ $+3,289641 \mathrm{NPL}$ and Fcount $(595,2748)>$ from Ftable $(2,3003)$ and the level of significance or probability (a) $0.000<0.05$. The variable contribution of Credit Effectiveness or Financing and Portfolio Management of Non-Performing Loans to the Asset Growth variable was $97.6182 \%$. while the remaining $2.3818 \%$ is influenced by other factors outside of the model.

\section{REFERENCES}

Ascarya, (2006), Akad dan produk Bank Syariah. Jakarta : PT. Raja Grafindo Persada

Effendy, A., \& Sunarsi, D. (2020). Persepsi Mahasiswa Terhadap Kemampuan Dalam Mendirikan UMKM Dan Efektivitas Promosi Melalui Online Di Kota Tangerang Selatan. Jurnal IImiah MEA (Manajemen, Ekonomi, \& Akuntansi), 4(3), 702-714. https://doi.org/10.31955/mea.vol4.is s3.pp702-714

Faud, M. Ramli, (2015), Akuntansi Perbankan Pendekatan Sisi Praktik, Bogor, Ghalia Indonesia

Gumilar, I., Sunarsi, D. (2020). Comparison of financial performance in banking with high car and low car (Study of banks approved in the kompas 100 index for the period 2013-2017). International Journal of Psychosocial Rehabilitation. Volume 24 - Issue 7

Heru Prestyo, Aries, (2011), Manajemen keuangan bagi manajer nonkeuangan., Jakarta : PPM

Karim, Adiwarman A., (2008), Bank Islam Analisis fiqih dan Keuangan. Jakarta: PT Raja Grafindo Persada

Kasmir, (2008), Dasar-dasar Perbankan Jakarta : PT Raja Grafindo Persada 
Kasmir, (2014), Bank dan Lembaga Keuangan Lain, edisi revisi 2014. Jakarta : RajawaliPers

Muhammad, (2005). Bank syariah problem dan prospek perkembangan di Indonesia.Yogyakarta : graha IImu

Nofiana, L., \& Sunarsi, D. (2020). The Influence of Inventory Round Ratio and Activities Round Ratio of Profitability (ROI). JASa (Jurnal Akuntansi, Audit dan Sistem Informasi Akuntansi), 4(1), 95-103.

Nurhayati, Sri \& Wasilah, (2009) ,Akuntansi Syariah di Indonesia, edisi dua, Jakarta :

Nuryani,Y. D Sunarsi. (2020). The Effect of Current Ratio and Debt to Equity Ratio on Deviding Growth. JASa (Jurnal Akuntansi, Audit dan Sistem Informasi Akuntansi) 4 (2), 304-312.

Purba, Kuras, (2019), Manajemen Perbankan, Bandung : Yrama Widya

Rinaldy, Eddie, (2009), Membaca Neraca Bank. Jakarta : CV Karya Gemilang

Rivai, Veithzal dan Arifin, Arviyan, (2010), Islamic Banking, Jakarta: Bumi Aksara, Salemba Empat

Sudjana, (1994), Metoda Statistika.Bandung: Tarsito

Sugiyono, (2019), Metode Penelitian Kuantitatif. Cetakan ke 2, Bandung: Alfabeta

Suharsimi Arikunto, (1998) .Manajemen Penelitian.Jakarta: Rineka Cipta

Sujarweni, V. Wiratna, 2015, Statistik Untuk Bisnis dan Ekonomi, cetakan pertama. Yogyakarta

Sunarsi, D. (2019). Penerapan MSDM Strategis Dalam Upaya Meningkatkan Kemampuan Organisasi dalam menyongsong Revolusi 4.0. Jurnal IImiah MEA (Manajemen, Ekonomi, \& Akuntansi), 3(1), 221-233. https://doi.org/10.31955/mea.vol3.is s1.pp221-233

Susanti, N., Latifa, I., \& Sunarsi, D. (2020). The Effects of Profitability, Leverage, and Liquidity on Financial Distress on Retail Companies Listed on Indonesian Stock Exchange. Jurnal IImiah IImu Administrasi Publik, 10(1), 45-52.
Syafi'i Antonio, Muhammad, (2001), Bank syariah dari teori ke praktik. Jakarta : Gema Insani Press

Undang Undang Republik Indonesia Nomor 10 Tahun (1998) tentang Perbankan.

Undang Undang Republik Indonesia Nomor 21 Tahun (2008) tentang Perbankan Syariah.

Undang Undang Republik Indonesia Nomor 7 Tahun (1992) tentang Perbankan

Zulganef, (2018), Metodologi penelitian bisnis dan Manajemen, Bandung : PT Refika Aditama. 